\title{
Antibacterial, antifungal and antioxidant activities of the ethanol extract of the stem bark of Clausena heptaphylla
}

\author{
Md Fakruddin ${ }^{*}$, Khanjada Shahnewaj Bin Mannan ${ }^{2 \dagger}$, Reaz Mohammad Mazumdar ${ }^{3+}$ and Hafsa Afroz ${ }^{4+}$
}

\begin{abstract}
Background: There is wide spread interest in drugs derived from plants as green medicine is believed to be safe and dependable, compared with costly synthetic drugs that have adverse effects.

Methods: We have attempted to evaluate the antioxidant, In vitro thrombolytic, antibacterial, antifungal and cytotoxic effects of Clausena heptaphylla (Rutaceae) stem bark extract ethanol extract.

Results: Ethanolic stem bark extract of Clausena heptaphylla (CHET) contains flavonoids, alkaloids, saponins and steroids but it lacks tannins, anthraquinones and resins. Phenol content of the extract was $13.42 \mathrm{mg} / \mathrm{g}$ and flavonoid content was $68.9 \mathrm{mg} / \mathrm{g}$. CHET exhibited significant DPPH free radical scavenging activity with $\mathrm{I}_{50}$ value of $3.11 \mu \mathrm{g} / \mathrm{ml}$. Reducing power of CHET was also moderately stronger. In the cytotoxicity assay, LC 50 and Chi-square value of the ethanolic extract against brine shrimp nauplii were $144.1461 \mu \mathrm{g} / \mathrm{ml}$ and 0.8533 demonstrating potent cytotoxic effect of the extract. In vitro thrombolytic activity of CHET is significant with $45.38 \%$ clot lysis capability compared to that of Streptokinase (65.78\%). In antibacterial screening, moderate zone of inhibition (6.5-9.0 mm in diameter) was observed against gram-positive Bacillus subtilis ATCC 11774, Bacillus cereus ATCC 10876, Staphylococcus aureus ATCC 25923, Bacillus polymyxa ATCC 842 and Bacillus megaterium ATCC 13578 and less promising zone of inhibition (3.0-4.5 mm in diameter) against gram-negative Salmonella typhi ATCC 65154, Shigella flexneri ATCC 12022, Proteus vulgaris ATCC 13315 and Escherichia coli ATCC 25922. Shigella sonnei ATCC 8992 did not show any sensitivity. The MIC values against these bacteria were ranged from 2,000 to 3,500 $\mu \mathrm{g} / \mathrm{ml}$. The extract showed significant zone of inhibition against Rhizopus oryzae DSM 2200, Aspergillus niger DSM 737 and Aspergillus ochraceus DSM 824 in antifungal assay.
\end{abstract}

Conclusions: Further advanced research is necessary to isolate and characterize the chemical components responsible for the therapeutic properties of the plant.

Keyword: Antioxidant, Antibacterial, Antifungal, Cytotoxic, Clausena heptaphylla

\section{Background}

Medicinal plants are an important therapeutic aid for various ailments [1]. Most of the people in rural and urban areas of the world depended on the medicinal plants for the treatment of infectious diseases [2].Today, there is wide spread interest in drugs derived from

\footnotetext{
* Correspondence: fakruddinmurad@gmail.com

${ }^{\dagger}$ Equal contributors

${ }^{1}$ Industrial Microbiology Laboratory, Institute of Food Science and

Technology (IFST). Bangladesh Council of Scientific and Industrial Research (BCSIR), Dhaka, Bangladesh

Full list of author information is available at the end of the article
}

plants. Medicinal plant extracts offer considerable potential for the development of new agents effective against infections currently difficult to treat [3]. As natural products have been elaborated within living systems, they are often perceived as showing more 'drug likeness' and biological friendliness than totally synthetic molecules, making them good candidates for further drug development [4].

Clausena heptaphylla (Roxb.) Wight and Arn. (Bengali name: Panbilash, Karanphul, Pomkaphur) is a small bushy shrub that is distributed throughout Bangladesh, India and other parts of south East Asia [5]. Clausena 
species are known to be useful in paralysis, ulcerated nose, headache, muscular pain and malarial fever [6]. They are also reputed as diuretic, astringent, insecticide, tonic and vermifuge [7]. The leaves of the plants possess antimicrobial properties [8,9]. A new carbazole alkaloid, named clausenal, was isolated from the leaves of $C$. heptaphylla and the alkaloid was found to be active against both Gram-positive and Gram-negative bacteria and fungi [10].

We have attempted to evaluate the antioxidant, In vitro thrombolytic, antibacterial, antifungal and cytotoxic effects of $C$. heptaphylla stem bark ethanolic extract in this study.

\section{Methods}

\section{Ethical statement}

All animal experiments were carried out on shrimp nauplii, for which ethical approval is not required. All human blood samples were obtained from consenting, healthy individuals. There are no ethical review bodies in Bangladesh, so it was not possible for us to obtain approval for this procedure.

\section{Media and chemicals}

DPPH (2,2-diphenyl-1-picrylhydrazyl), TCA (trichloroacetic acid) and ferric chloride were obtained from Sigma Chemical Co. USA; Ascorbic acid was from SD Fine Chem. Ltd. India, ammonium molybdate from Merck, Germany. Mueller-Hinton broth and agar media (Hi media, India), final PH $7.3 \pm 0.2$ (at $25^{\circ} \mathrm{C}$ ), was used for MIC determination and antibacterial. On the other hand, potato dextrose agar media (Hi media, India), final $\mathrm{PH}$ (at $\left.25^{\circ} \mathrm{C}\right) 5.6 \pm 0.2$ and artificial seawater $(3.8 \% \mathrm{NaCl}$ solution) were used for the determination of antifungal and cytotoxic effect [1].

\section{Collection of plant material}

The stem bark of C. heptaphylla was collected from Jhalokathi, Bangladesh in june 2011 and was identified. The plant was identified by Sarder Nasir Uddin (Taxonomist, Bangladesh National Herbarium, Ministry of Environment and Forest, Dhaka, Bangladesh). A voucher specimen is preserved in Bangladesh National Herbarium with the accession No. DACD- 52876.

\section{Extraction of plant material}

The fresh stem barks of $C$. heptaphylla were washed with water immediately after collection. Then chopped into small pieces, air dried at room temperature for about 10 days and pulverized into powder $(1 \mathrm{~kg})$ which was macerated in $6 \mathrm{~L}$ pure ethanol for 7 days at room temperature $(23 \pm 5)^{\circ} \mathrm{C}$. After 7 days, extract was filtered off through cotton plug and finally with a Whatman No. 1 filter paper. Then extract was concentrated under reduced pressure below $50^{\circ} \mathrm{C}$ through rotatory vacuum evaporator (RE200 Sterling, UK). The concentrated extract (45 gm blackish-green, $4.5 \% \mathrm{w} / \mathrm{w}$ yield) was stored at $4^{\circ} \mathrm{C}[11]$.

\section{Phytochemical screening}

To identify the chemical constituents of plant extract standard procedures were followed. Freshly prepared crude extracts of $C$. heptaphylla were qualitatively tested for the presence of chemical constituents using the following reagents and chemicals, flavonoids with the use of $\mathrm{Mg}$ and $\mathrm{HCl}$; tannins with ferric chloride and potassium dichromate solutions and saponins with ability to produce stable foam and steroids with Libermann Burchard reagent, reducing sugars with Benedict's reagent and observed color change in respective [12].

\section{Determination of total phenolic content}

Folin-Ciocalteu method was used to determine the total phenolic content; Folin-Ciocalteu oxidized the extract whereas sodium carbonate neutralized it. Blue color formed and the absorbance was measured at $760 \mathrm{~nm}$ after 60 min by using gallic acid (GA) as standard. Total Phenolic content was expressed as mg GA equivalent/ gm of extract [13].

\section{Determination of total flavonoid content}

Method described by Meda et al. [14] was followed to determine the flavonoid content where quercetin was used as standard. $1 \mathrm{mg}$ of plant extract in methanol was mixed with $1 \mathrm{ml}$ of aluminium trichloride in Ethanol $(20 \mathrm{mg} / \mathrm{ml})$ and a drop of acetic acid was added. Then diluted up to $25 \mathrm{ml}$ with ethanol and measured the absorbance at $415 \mathrm{~nm}$ after $40 \mathrm{~min}$. The absorption of blank samples and standard quercetin solution $(0.5 \mathrm{mg} / \mathrm{ml})$ in methanol was measured under the same conditions [14].

\section{DPPH radical scavenging activity}

The antioxidant activity of $C$. heptaphylla ethanolic stem bark extract and the standard antioxidant ascorbic acid was assessed on the basis of the radical scavenging effect of the stable 2,2- diphenyl-1-picrylhydrazyl (DPPH) free radical activity according to the method described by Brand-Williams et al. [15]. C. heptaphylla ethanolic extract with different concentrations $(10,50,100,200,400$, 600,800 and $1000 \mu \mathrm{g} / \mathrm{ml}$ ) were prepared in ethanol. Ascorbic acid was used as standard in 1- $100 \mu \mathrm{g} / \mathrm{ml}$ solution. The scavenging activity against DPPH was calculated using the following equation: Scavenging activity $(\%)=[(\mathrm{A}-\mathrm{B}) / \mathrm{A}] \mathrm{x} 100$, Where $\mathrm{A}$ was the absorbance of control (DPPH solution without the sample), B was the absorbance of DPPH solution in the presence of the sample (extract/ascorbic acid). Then, \% scavenging activity was plotted against log concentration and from 
the graph $\mathrm{IC}_{50}$ (Inhibition concentration 50) value was calculated by linear regression analysis.

\section{Reducing power}

The reducing power of $C$. heptaphylla extract was determined according to the method of Oyaizu [16]. Different concentration of $C$. heptaphylla extract in $1 \mathrm{ml}$ of distilled water was mixed with phosphate buffer $(2.5 \mathrm{ml}$, $0.2 \mathrm{M}, \mathrm{pH} 6.6)$ and potassium ferricyanide $\left[\mathrm{K}_{3} \mathrm{Fe}(\mathrm{CN})_{6}\right]$ $(2.5 \mathrm{ml}, 1 \%)$ then the mixture was incubated at $50^{\circ} \mathrm{C}$ for $20 \mathrm{~min}$. Trichloroacetic acid (10\%) slightly added $(2.5 \mathrm{ml})$ to the mixture and centrifuged at 3,000 rpm for $10 \mathrm{~min}$. The upper layer of the solution $(2.5 \mathrm{ml})$ was mixed with distilled water $(2.5 \mathrm{ml})$ and $\mathrm{FeCl}_{3}(0.5 \mathrm{ml}$, $0.1 \%$ ) then taken the absorbance at $700 \mathrm{~nm}$. The reference standard was Ascorbic acid and the Blank solution contained Phosphate buffer [16].

\section{Brine shrimp lethality bioassay}

Cytotoxic activity of ethanolic stem bark extract was determined by Brine-Shrimp Lethality assay as described by Meyer et al. [17]. Simple zoological organism (Artemia) was used as a convenient monitor for the screening. The eggs of the brine shrimp were hatched in artificial seawater $(3.8 \% \mathrm{NaCl}$ solution) for 48 hours to mature shrimp called nauplii. Then $30 \mathrm{mg}$ of C. heptaphylla stem bark extract were separately dissolved in $3 \mathrm{ml}$ of DMSO, and from these 1000, 500, 250, 125 and $62.5 \mu \mathrm{g} / \mathrm{ml}$ were prepared by serial dilution. Each concentration was tested in triplicate, giving a total of 15 test tubes for each sample. A control containing $5 \mathrm{ml}$ of DMSO solvent was used for each solvent. The final volume of the solution in each test-tube was made up to $5 \mathrm{ml}$ with seawater immediately after adding shrimp larvae. The test tubes were maintained under illumination. After 24 hours have elapsed, Survivors were counted with the aid of a $3 \mathrm{x}$ magnifying glass. The $\mathrm{LC}_{50}$ values were calculated from Probit Chart using computer software "BioStat-2007".

\section{In vitro thrombolytic activity}

Individuals from whom the blood samples were collected were informed and upon their consent they were included in this study. Samples were taken from adult healthy individual. No children were included in this study. In vitro thrombolytic activity was performed according to Ratnasooriya et al. [18].The extract was suspended in $10 \mathrm{ml}$ distilled water and shaken vigorously on a vortex mixer. Then the suspension was kept overnight and decanted to remove the soluble supernatant, which was filtered through a filter paper (Whatman No. 1). The solution was then ready for in vitro evaluation of clot lysis activity [19]. Commercially available lyophilized Streptokinase vial (Polamin Werk GmbH, Herdecke,
Germany) of 15,00,000 I.U., $5 \mathrm{ml}$ sterile distilled water was added and mixed properly. This suspension was used as a stock from which $100 \mu \mathrm{l}(30,000 \mathrm{I}$.U) was prepared for in vitro thrombolysis. Experiments for clot lysis were carried as reported earlier (Prasad et al., 2007). Venous blood drawn from healthy volunteers was transferred in different pre-weighed sterile eppendorf tube $\left(500 \mu \mathrm{l} /\right.$ tube) and incubated at $37^{\circ} \mathrm{C}$ for 45 minutes. After clot formation, serum was completely removed (aspirated out without disturbing the clot formed). Each tube having clot was again weighed to determine the clot weight (Clot weight $=$ weight of clot containing tube weight of tube alone). Each eppendorf tube containing clot was properly labeled and $100 \mu \mathrm{l}$ of plant extract was added to the tubes. All the tubes were then incubated at $37^{\circ} \mathrm{C}$ for 90 minutes and observed for clot lysis. After incubation, fluid obtained was removed and tubes were again weighed to observe the difference in weight after clot disruption. Difference obtained in weight taken before and after clot lysis was expressed as percentage of clot lysis. Streptokinase and water were used as a positive and negative (non-thrombolytic) control respectively. The experiment was repeated several times with the blood samples of different volunteers. Clot lysis was calculated by the following formula:

$$
\begin{aligned}
\% \text { clotlysis }= & (\text { Weightofthelysisclot } / \\
& \text { Weightofclotbeforelysis }) \times 100
\end{aligned}
$$

\section{Antibacterial assay}

In vitro antibacterial screening was carried out by disc diffusion method [20] against 6 gram-positive (Bacillus subtilis, Staphylococcus aureus, Bacillus cereus, Bacillus polymyxa, Bacillus megaterium, Enterococcus faecalis) and 8 gram-negative bacteria (Salmonella typhi, Klebsiella sp., Shigella flexneri, Shigella sonnei, Proteus sp., E. coli, Vibrio cholerae, Pseudomonas aeruginosa). The bacterial suspension turbidity adjusted to McFarland standard number 0.5, in Mueller Hinton Broth (Himedia, India). With a sterile cotton swab bacterial culture was streaked on previously prepared Mueller Hinton agar plate (Himedia, India). Dried and sterilized paper discs were treated separately with desired concentration of previously prepared ethanolic solution of the root extract using a micropipette dried in air under aseptic condition and placed at equidistance in a circle on the seeded plate. The concentrations of root extract used were $2 \mathrm{mg} / \mathrm{disc}$ and $3 \mathrm{mg} /$ disc. These plates were kept for 4-6 hours at low temperature and the test materials diffuse from disc to the surrounding medium by this time. The plates were then incubated at $37^{\circ} \mathrm{C}$ for 18 hours. The diameter of zone of inhibition produced by root extract was then compared with standard 
antibiotic Kanamycin (30 $\mu \mathrm{g} /$ disc). Each sample was used in triplicate for the determination of antibacterial activity. Blank disc impregnated with solvent ethanol followed by drying off was used as negative control.

\section{Determination of MIC}

Minimum inhibitory concentrations (MIC) of crude extract of the $C$. heptaphylla were performed by macrodilution method [21]. The crude extract was dissolved in 30\% dimethyl sulfoxide (DMSO) to obtain 10\% (w/v) solution. For MIC test of the selected bacteria, the extract was first diluted in sterilized Mueller-Hinton broth to the highest concentration of $10,000 \mu \mathrm{g} / \mathrm{ml}$ and then dilution were performed at concentration of $5000 \mu \mathrm{g} / \mathrm{ml}, 4000 \mu \mathrm{g} / \mathrm{ml}$, $3500 \mu \mathrm{g} / \mathrm{ml}, 3000 \mu / \mathrm{ml}, 2500 \mu / \mathrm{ml}, 2000 \mu \mathrm{g} / \mathrm{ml}, 1500 \mu \mathrm{g} / \mathrm{ml}$, $1000 \mu \mathrm{g} / \mathrm{ml}, 750 \mu \mathrm{g} / \mathrm{ml}, 500 \mu \mathrm{g} / \mathrm{ml}$ and $250 \mu \mathrm{g} / \mathrm{ml}$ in screw caped tube containing broth medium. Bacterial suspensions of the test organism were prepared in sterilized Mueller-Hinton broth. Then $1 \mathrm{ml}$ of the dilution was added to each sterilized screw capped tube containing $1 \mathrm{ml}$ of compound suitably diluted in the sterilized broth medium to give final volume of $2 \mathrm{ml}$. Culture medium without samples and others without microorganisms were used in the tests as control. Tubes were incubated at $37^{\circ} \mathrm{C}$ for 20-24 hours and growth was indicated by turbidity.

\section{Antifungal assay}

The poisoned food technique [22] was used to screen for antifungal activity. Potato dextrose agar (PDA) was used as a culture medium. From this required concentration of extract was taken by sterilized pipette in a sterilized petriplate and then $15 \mathrm{ml}$ medium was poured into the petriplate and mixed well and allowed to solidify. Inoculation was done at the center of each plate with $5 \mathrm{~mm}$ mycelium block for each fungus. The mycelium block was prepared with the help of cork borer from the growing area of a 5 days old culture of the test fungi on PDA. The blocks were placed at the center of each petriplate in an inverted position to get greater contact of the mycelium with the culture medium. The inoculated plates were incubated at $(25 \pm 2)^{0} \mathrm{C}$. Proper control (PDA without extract) was also maintained. Diameter of fungal colonies was measured after 5 days of incubation. The average of triplicate of measurements was taken as colony diameter of the fungus in millimeters. The percentage inhibition of mycelial growth of the test fungus was calculated by the following formula:

$$
\mathrm{I}=(\mathrm{C}-\mathrm{T}) / \mathrm{C} \times 100
$$

where, I=Percentage of Inhibition, $C=$ Diameter of the fungal colony in control, $\mathrm{T}=$ Diameter of the fungal colony in treatment [11].

\section{Statistical analysis}

All the in vitro experimental results were given as mean \pm SEM of three parallel measurements and data were evaluated by using student's t-test. $\mathrm{P}$ values $<0.001$ were regarded as significant. Results were processed by Excel (2007) and BioStat [23,24].

\section{Results}

\section{Phytochemical screening}

Qualitative Phytochemical tests of Clausena heptaphylla were performed for the ethanol extract of the bark of stem. The results of various chemical tests for the detection and identification of chemical constituents were summarized in Table 1. The table indicates the presence of some chemical constituents present in the plant parts.

\section{Total phenol and flavonoid content}

The total phenol and total flavonoid contents of Clausena heptaphylla of ethanol extract were expressed in Gallic acid and Quercetin equivalents respectively. Total phenolic content was $13.42 \mathrm{mg} / \mathrm{g}$ Gallic acid equivalent and total flavonoid content was $68.9 \mathrm{mg} / \mathrm{g}$ Quercetin equivalent.

Different studies suggest that different types of polyphenolic compounds such as flavonoids, phenolic acids which are found in plants have multiple biological effects, including antioxidant activity [25].

\section{DPPH free radical scavenging activity}

The antioxidant activity of the extract was assessed by the DPPH free radical scavenging assay as shown in Figure 1. The stem bark extract exhibited significant DPPH free radical scavenging effects compared to standard ascorbic acid. Where, $\mathrm{IC}_{50}$ value of ascorbic acid was $5.15 \mu \mathrm{g} / \mathrm{ml}$ and stem bark extract was $3.11 \mu \mathrm{g} / \mathrm{ml}$.

Antioxidant activity of $C$. heptaphylla extract was measured by DPPH free radical scavenging method and

\section{Table 1 Result of phytochemical screening of ethanol} stem bark extract of $C$. heptaphylla

\begin{tabular}{lc}
\hline Tests & CHET \\
\hline Flavonoid & + \\
Tannin & - \\
Glycoside & + \\
Alkaloid & + \\
Anthraquinone & - \\
Carbohydrate & + \\
Resin & - \\
Protein & - \\
Saponins & + \\
Steroids & + \\
\hline
\end{tabular}

(CHET denote for ethanolic extracts of Clausena heptaphylla; $(+)=$ present; $(-)=$ Absent). 


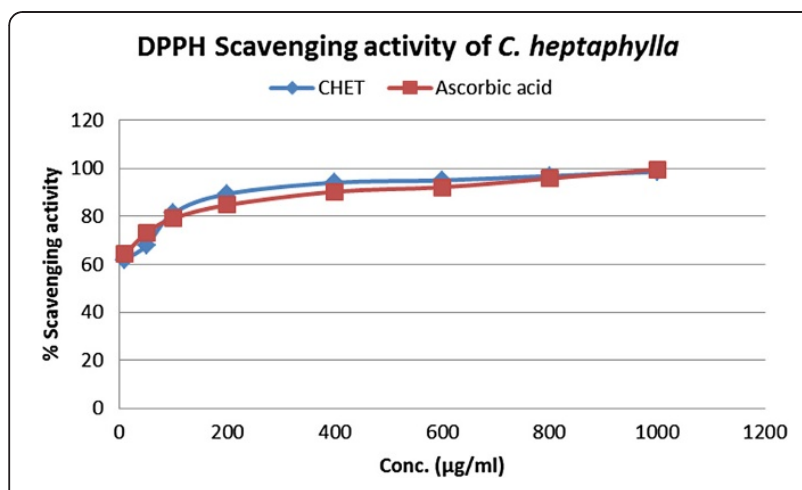

Figure 1 Relative percentage scavenging activity of standard antioxidant ascorbic acid and CHET extract.

their scavenging activity was compared with the standard antioxidant ascorbic acid. Both ascorbic acid and extract showed a dose dependent activity. However, extract showed very strong DPPH free radical scavenging effect in regard to ascorbic acid. Among seven different concentrations used in the study (10 to $1000 \mu \mathrm{g} / \mathrm{ml}$ ) $1000 \mu \mathrm{g} / \mathrm{ml}$ showed the highest scavenging activity 98.64\% whereas ascorbic acid of the same concentration showed $99.65 \%$ which are very close to each other (Figure 1). Percent (\%) scavenging activity was plotted against $\log$ concentration and from the graph $\mathrm{IC}_{50}$ (Inhibition concentration 50) value was calculated by linear regression analysis. $\mathrm{IC}_{50}$ value of ascorbic acid and extract was found $5.15 \mu \mathrm{g} / \mathrm{ml}$ and $3.11 \mu \mathrm{g} / \mathrm{ml}$, respectively.

\section{Reducing power}

The reducing power of a compound is related to its electron transfer ability and may therefore; serve as an indicator of its potential antioxidant activity [26]. By using the potassium ferricyanide reduction method the reductive capabilities of the plant extracts was identified in comparison with ascorbic acid. The reducing power of the extracts was moderately strong while increasing dose it shows little increment. At $100 \mu \mathrm{g} / \mathrm{ml}$ concentration, reducing power of CHET was 0.73 whereas that of ascorbic acid was 0.85 . But, with increasing concentration $(100-200 \mu \mathrm{g} / \mathrm{ml})$, reducing power of CHET increased from 0.73 to 0.89 whereas that of ascorbic acid increased from 0.85 to 1.54 .

\section{Brine shrimp lethality bioassay}

Cytotoxic effect of the extract is summarized in the Figure 2. In cytotoxic bioassay, the $\mathrm{LC}_{50}$ value of $\mathrm{CHET}$ was $144.1461 \mu \mathrm{g} / \mathrm{ml}$.

\section{In Vitro clot lysis assay}

Addition of $100 \mu \mathrm{l}$ Streptokinase (SK), a positive control (30,000 I.U.) to the clots along with 90 minutes of incubation at $37^{\circ} \mathrm{C}$, showed $69.35 \pm 1.88 \%$ clot lysis. Clots

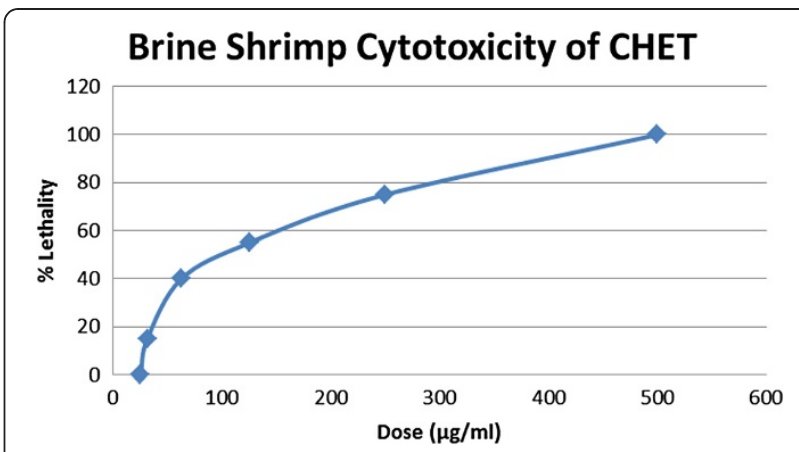

Figure 2 Brine Shrimp Cytotoxicity of Ethanol Extract of $C$. heptaphylla (CHET).

when treated with $100 \mu \mathrm{l}$ sterile distilled water (negative control) showed only negligible clot lysis (6.23\%). The mean difference in clot lysis percentage between positive and negative control was very significant $(p<0.0001)$. The in vitro thrombolytic activity study revealed that Clausena heptaphylla showed $44.64 \pm 2.78 \%$ clot lysis and Clausena heptaphylla in combination with Streptokinase showed $74.23 \pm 1.79 \%$ clot lysis activity. Percent clot lysis obtained after treating clots with herb and appropriate controls is shown in Figure 3. Statistical representation of the effective clot lysis percentage by our herbal preparation, positive thrombolytic control (Streptokinase) and negative control (sterile distilled water) is tabulated in Additional file 1: Table 3.

Statistical representation of the effective clot lysis percentage by herbal preparations, positive thrombolytic control (Streptokinase) and negative control (sterile distilled water) were done by paired $\mathrm{t}$-test analysis; clot lysis $\%$ is represented as mean \pm S.D. and $p$ of herbal preparation (C. heptaphylla) was $<0.05$; which was considered as significant.

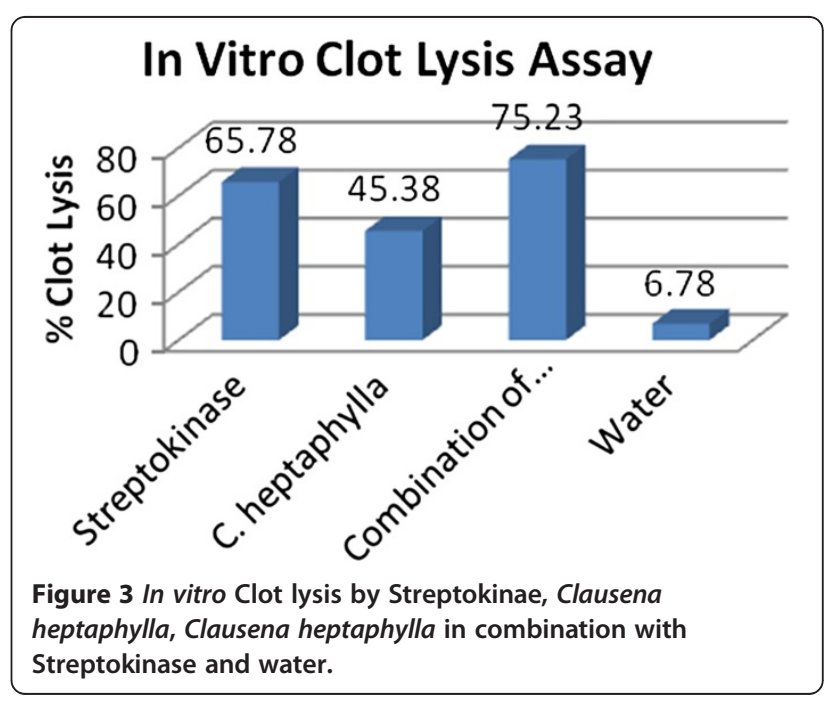




\section{Antibacterial assay}

CHET showed antibacterial activity as measured by zone of inhibition against all the bacteria tested except Shigella sonnei. CHET showed better antibacterial activity against gram-positive bacteria than gram-negative. Highest activity was demonstrated against Enterococcus faecalis and lowest against Vibrio cholerae. Again better antibacterial activity was demonstrated with $4 \mathrm{mg} /$ disc concentration than $2 \mathrm{mg} /$ disc concentration.

\section{Determination of MIC}

The MIC value against Gram-positive and Gramnegative bacteria ranged from 2,000 to $3,500 \mu \mathrm{g} / \mathrm{ml}$, respectively (Table 2). Lowest MIC value $(2000 \mu \mathrm{g} / \mathrm{ml})$ of CHET was against Bacillus subtilis and Proteus sp. MIC value was higher $(3500 \mu \mathrm{g} / \mathrm{ml})$ against Klebsiella sp., Salmonella typhi and Shigella sonnei. MIC value was much higher than control antibiotic, Doxycycline $(30 \mu \mathrm{g} / \mathrm{ml})$. Considering the impurities and complex composition of the extract, MIC value against the pathogens included in this study was promising though Doxycycline had much lower MIC value.

\section{Antifungal assay}

The anti-fungal potentials of the stem bark extract of $C$. heptaphylla were assessed against 5 fungal species. The results (diameter of zone of inhibition) were compared with the standard drug, Fluconazole (100 $\mu \mathrm{g} / \mathrm{disc})$. $C$. heptaphylla extract showed strong antifungal activity against the tested fungi (Table 3). All the tested fungi were susceptible to ethanolic stem bark extract of $C$. heptaphylla. CHET produced almost similar zone diameter compared with the standard drug in a very lower concentration (4-6 $\mu \mathrm{g})$ compared to standard drug (100 $\mu \mathrm{g})$.

\section{Discussion}

Plants produce a huge variety of secondary compounds as natural protection against microbial and insect attack. Some of these compounds are toxic to animals, but others may not be toxic. Indeed, many of these compounds have been used in the form of whole plants or plant extracts for food or medical applications in human [27] because plants are the natural reservoir of many antimicrobial, anticancer agents, analgesics, anti-diarrheal, antifungal as well as various therapeutic activities [28]. Acceptance of medicines from such plant origin as an alternative form of healthcare is increasing because they are serving as promising sources of novel antibiotic prototypes [29]. Some of the phytochemical compounds e.g. glycoside, saponin, tannin, flavonoids, terpenoid, alkaloids, have variously been reported to have antimicrobial activity [30].

Ethanolic stem bark extract of Clausena heptaphylla (CHET) contains flavonoids, alkaloids, saponins and steroids but it lacks tannins, anthraquinones \& resins. Phenol content of the extract is $13.42 \mathrm{mg} / \mathrm{g}$ and flavonoid content is $68.9 \mathrm{mg} / \mathrm{g}$.

Free radicals from oxidative stress are involved in many disorders like atherosclerosis, angina pectoris, neurodegenerative diseases and cancer. Antioxidants due to their scavenging activity are useful for the management of those diseases. The quantitative determination of antioxidants explored that high quantity of scavenging substances are found to be [31] in C. heptaphylla which plays the key role in showing free radical scavenging

Table 2 Minimum Inhibitory Concentration of CHET and Doxycycline

\begin{tabular}{|c|c|c|c|c|}
\hline \multirow[t]{2}{*}{ Test organism } & & \multirow[t]{2}{*}{ Source ID (ATCC) } & \multicolumn{2}{|r|}{ MIC value } \\
\hline & & & CHET $(\mu \mathrm{g} / \mathrm{ml})$ & Doxycycline hydrochloride $(\mu \mathrm{g} / \mathrm{ml})$ \\
\hline \multirow[t]{6}{*}{ Gram-positive } & Bacillus subtilis & 11774 & 2000 & 5.0 \\
\hline & Staphylococcus aureus & 25923 & 2500 & 5.5 \\
\hline & Bacillus cereus & 10876 & 2500 & 4.5 \\
\hline & Bacillus polymyxa & 842 & 3000 & 6.0 \\
\hline & Bacillus megaterium & 13578 & 3000 & 5.5 \\
\hline & Enterococcus faecalis & 29212 & 3000 & 4.5 \\
\hline \multirow[t]{8}{*}{ Gram-negative } & Salmonella typhi & 65154 & 3500 & 5.5 \\
\hline & Shigella flexneri & 12022 & 3000 & 6.0 \\
\hline & Klebsiella pneumoniae & 13883 & 3500 & 6.5 \\
\hline & Shigella sonnei & 8992 & 3500 & 5.5 \\
\hline & Proteus vulgaris & 13315 & 2000 & 4.5 \\
\hline & E. coli & 25922 & 2500 & 5.0 \\
\hline & Vibrio cholerae & 15748 & 3000 & 5.0 \\
\hline & Pseudomonas aeruginosa & 27853 & 2500 & 4.5 \\
\hline
\end{tabular}


Table 3 In-vitro antifungal activity of CHET and fluconazole

\begin{tabular}{llllll}
\hline Organism & Source & ID & \multicolumn{2}{c}{ \% inhibition } \\
\cline { 5 - 6 } & & & CHET (4 mg) & CHET (6 mg) & Fluconazole (100 $\mathbf{~ g})$ \\
\hline Aspergillus ustus & DSM & 63535 & 29.56 & 35.67 & 45 \\
Aspergillus niger & DSM & 737 & 37.87 & 41.98 & 65 \\
Aspergillus ochraceus & DSM & 824 & 39.98 & 43.66 & 41 \\
Penicillium chrysogenum & DSM & 1075 & 31.23 & 39.89 & 48 \\
Rhizopus oryzae & DSM & 2200 & 32.23 & 40.78 & 46 \\
\hline
\end{tabular}

activity of this plant. CHET exhibited significant DPPH free radical scavenging activity with $\mathrm{IC}_{50}$ value of 3.11 $\mu \mathrm{g} / \mathrm{ml}$. Reducing power of CHET is also moderately strong.

Brine shrimp lethality is a general bioassay which is indicative of cytotoxicity, antibacterial activities, pesticidal effects and various pharmacologic actions [32]. In this research, six different concentrations $(25,31.25,62.5$, $125,250,500 \mu \mathrm{g} / \mathrm{ml}$ ) of C. heptaphylla extract were used to determine its cytotoxicity by brine shrimp lethality bioassay (Figure 2). The extract showed lethality in a dose dependent manner. $\mathrm{LC}_{50}$ value of $\mathrm{C}$. heptaphylla ethanol extract was found $144.1461 \mu \mathrm{g} / \mathrm{ml}$ at confidence limit 95\% with chi-square value of 0.8533 (Figure 1). The $\mathrm{LC}_{50}$ value found in this study to be very significant suggesting the ethanol extract of $C$. heptaphylla has high potentiality to kill cancer cells as well as pests [32]. This significant lethality of the crude plant extract (as $\mathrm{LC}_{50}$ value less than $100 \mathrm{ppm}$ or $\mu \mathrm{g} / \mathrm{ml}$ ) to brine shrimp is indicative of the presence of potent cytotoxic compounds which warrants further investigation.

In vitro thrombolytic activity of CHET is significant with $45.38 \%$ clot lysis capability compared to that of Streptokinase (65.78\%) it can be considered for compound isolation in order to detect future anti-tumour compounds.

In antibacterial screening, moderate zone of inhibition (6.5-9.0 $\mathrm{mm}$ in diameter) were observed against grampositive Bacillus subtilis, Bacillus cereus, Staphylococcus aureus, Bacillus polymyxa and Bacillus megaterium and less promising zone of inhibition (3.0-4.5 mm in diameter) against gram-negative Salmonella typhi, Shigella flexneri, Proteus sp. and Escherichia coli. Shigella sonnei did not show any sensitivity. Stem bark extract showed significant zone of inhibition against Rhizopus spp., Aspergillus niger and Aspergillus ochraceus in antifungal assay.

CHET showed zone of inhibition to almost all the strains (at dose $2 \mathrm{mg}$ and $4 \mathrm{mg} /$ disc) except Shigella soneii. Crude extract at the concentration of $2 \mathrm{mg} / \mathrm{disc}$ showed 5.5, 6.0, 5.9, 6.2 and $6.4 \mathrm{~mm}$ zone of inhibition diameter against Gram-positive Bacillus subtilis, Staphylococcus aureus, Bacillus cereus, Bacillus polymyxa and Bacillus megaterium, respectively and 3.1, 2.5, 1.8, $3.6 \mathrm{~mm}$ diameter against Gram-negative Salmonella typhi, Shigella flexneri, Proteus sp. and E. coli. On the other hand, standard antibiotic Kanamycin $(30 \mu \mathrm{g} /$ disc) showed significant antibacterial activity against all tested grampositive and Gram-negative bacteria. Results implicated that the Gram-positive bacteria were more sensitive to the extract than the gram-negative bacteria. Bacillus megaterium, Enterococcus faecalis, Staphylococcus aureusand Klebsiella spp. were the most susceptible bacteria in this study (see Additional file 1). In a previous study, ethanolic stem bark extract of Terminalia arjuna showed 8-12 $\mathrm{mm}$ zone of inhibition diameter at $2 \mathrm{mg} /$ disc concentration and $12-16 \mathrm{~mm}$ zone diameter at $4 \mathrm{mg} /$ disc concentration against multi-antibiotic resistant Vibrio cholerae [33]. CHET has almost similar activity as Terminalia arjuna in this study. The present study justifies the claimed uses of $C$. heptaphylla in the traditional system of medicine to treat various infectious diseases caused by the microbes. The obtained results may provide a support to use of the plant in traditional medicine. Based on this, further chemical and pharmacological investigations to isolate and identify minor chemical constituents in C. heptaphylla and to screen other potential bioactivities may be recommended.

The MIC values against these bacteria were ranged from 2,000 to 3,500 $\mu \mathrm{g} / \mathrm{ml}$. The lowest MIC $(2000 \mu \mathrm{g})$ was recorded against Bacillus subtilis and the highest MIC $(3500 \mu \mathrm{g})$ recorded against Salmonella typhi and Shigella sonnei.C. heptaphylla showed a significant degree of anti-fungal activity (Table 2). The maximum antimycotic activity $43.66 \%$ was shown against $A$. ochraceus. Plant natural compounds are important source of mycotoxic compounds and they may provide a renewable source of useful fungicides that can be utilized in antimycotics drugs against infection of $A$. ochraceus. The effect of extract against $A$. niger was also higher implying that this plant can be utilized as anti-mycotics drugs against infection of $A$. niger in patients with pulmonary tuberculosis [34]. Moderate anti-mycotic effect was found against Aspergillus ustus at the concentration of 4 and $6 \mathrm{mg} / \mathrm{ml}$. Fluconazole was used as standard antifungal agent to compare the potentials of extract (Table 3). There are, however, alarming reports of opportunistic fungal infections which describe that the resistance of the organisms increased due to indiscriminate use of commercial anti- 
microbial drugs commonly used for the treatment of infectious disease. This situation forced the researchers to search for new anti-microbial substance from various sources including medicinal plant [34]. Our research findings revealed that medicinal plant $C$. heptaphylla can play a vital role in combating fungal resistance.

\section{Conclusions}

This study delineates that $C$. heptaphylla extract possesses some potentials in free-radical scavenging activity and cytotoxic effect but it has low antimicrobial (antibacterial and antifungal) activity. Since, crude ethanol extract of $C$. heptaphylla showed antibacterial and cytotoxic effect, it can be assumed that different active secondary metabolites were present in this extract. However, further studies are necessary to elucidate the mechanism lying with these effects. This study may serve as a foot step regarding the biological and pharmacological activities of stem bark extract of $C$. heptaphylla.

\section{Additional file}

Additional file 1: Figure1. Relative percentage scavenging activity of standard antioxidant ascorbic acid and CHET extract. Figure 2: Reducing potential of $C$. heptaphylla. Figure 3: Probit analysis for brine shrimp treated with CHET. Table 1: DPPH Scavenging activity of C. heptaphylla. Table 2: Brine Shrimp Cytotoxicity of Ethanol Extract of C. heptaphylla. Table 3+: Effect of ethanolic stem bark extract of $C$. heptaphylla and streptokinase (Positive control) on in vitro clot lysis. Table 4: In-vitro antibacterial activity of CHET and Kanamycin.

\section{Competing interests}

The authors declare that they have no competing interests.

\section{Authors' contributions}

MF planned the research work and collected the plant and drafted the manuscript. KSBM performed the antioxidant activity assay and in vitro thrombolytic assay. RMM has performed the antibacterial and antifungal and brine shrimp lethality assay. HA performed the phytochemical screening assay and reducing power assay. All authors read and approved the final manuscript.

\section{Acknowledgement}

The authors acknowledge Abhijit Chowdhury and Md. Nur Hossain, Scientific Officer, IFST, BCSIR, Dhaka for reviewing the manuscript critically.

\section{Author details}

${ }^{1}$ Industrial Microbiology Laboratory, Institute of Food Science and Technology (IFST). Bangladesh Council of Scientific and Industrial Research (BCSIR), Dhaka, Bangladesh. ${ }^{2}$ Center For Food \& Waterborne Diseases, icddr,b, Dhaka, Bangladesh. ${ }^{3}$ BCSIR Laboratories- Chittagong, Chittagong, Bangladesh. ${ }^{4}$ Department of Microbiology, Primeasia University, Dhaka, Bangladesh.

Received: 14 May 2012 Accepted: 23 November 2012 Published: 27 November 2012

\section{References}

1. Das J, Mannan A, Rahman MM, Dinar MAM, Uddin ME, Khan IN, Habib MR, Hasan N: Chloroform and Ethanol Extract of Spondias Pinnata and its Different Pharmacological activity Like- Antioxidant, Cytotoxic, Antibacterial Potential and Phytochemical Screening through In-Vitro Method. Int J Res Pharma Biomed Sci 2011, 2(4):1806-1812.
2. Rahman MS, Junaid M: Antimicrobial Activity of Leaf Extracts of Eupatorium Triplinerve Vehl. against Some Human Pathogenic Bacteria and Phytopathogenic Fungi. Bang J Bot 2008, 37(1):89-92.

3. Machado TB, Leal ICR, Amaral ACF, Kuster RM, Kokis VM, Silva MG, Santos KRN: Brazilian phytopharmaceuticals evaluation against hospital bacteria. Phyto Ther Res 2005, 19:519-525.

4. Minhajur RM, Alam MM, Shahriar M, Moghal MR, Siddiqui R: The Antimicrobial activity and Brine Shrimp Lethality Bioassay of Leaf extracts of Stephania japonica (Akanadi). Bang J Microbiol 2011, 28(2):52-56.

5. Haque AM: Plant names of Bangladesh. Dhaka: Bangladesh National Herbarium. Ministry of Environment and Forest; 1987:137-214.

6. Yusuf M, Chowdhury JU, Wahab MA, Begum J: Medicinal plants of Bangladesh. Chittagong, Bangladesh: BCSIR Laboratories; 1994:177.

7. Perry LM: Medicinal Plants of East and Southeast Asia. Cambridge, USA: The MIT Press; 1980:231.

8. Sohrab MH, Mazid MA, Rahman E, Hasan CM, Rashid MA: Antibacterial activity of Clausena heptaphylla. Fitoterapia 2001, 72(5):547-549.

9. Begum R, Kaisar MA, Rahman MS, Chowdhury AMS, Rahman MM, Hasan CM, Rashid MA: Claudenolide-1-methyl ether from Clausena heptaphylla W \& A. Bol Latinoamericano Caribe Plantas Medicin Aromá 2011, 10(2):136-138.

10. Chakraborty A, Saha C, Podder G, Chowdhury BK, Bhattacharyya P: Carbazole alkaloid with antimicrobial activity from Clausena heptaphylla. Phytochemistry 1995, 38(3):787-789.

11. Rahman MA, Chakma JS, Islam S, Ahmed NU: Evaluation of antioxidant antibacterial, antifungal and cytotoxic effects of Clausena suffruticosa ethanolic root extract. J Appl Pharma Sci 2011, 1(5):90-95.

12. Ghani A: Medicinal Plants of Bangladesh. 2nd edition. Dhaka: The Asiatic Society of Bangladesh; 2003:603.

13. Singelton VR, Orthifer $R$, Lamuela-Raventos RM: Analysis of total phenols and other oxidation substrates and antioxidants by means of FolinCiocalteu reagent. Methods Enzymol 1999, 299:152-175.

14. Meda A, Lamien CE, Romito M, Millogo J, Nacoulma OG: Determination of the total phenolic, flavonoid and proline contents in burkina fasan honey, as well as their radical scavenging activity. Food Chem 2005, 91:571-577.

15. Brand-Williams W, Cuvelier ME, Berset C: Use of a free radical method to evaluate antioxidant activity. Food Sci Technol 1995, 28:25-30.

16. Oyaizu M: Studies on product of browning reaction prepared from glucose amine. Jpn J Nutr 1986, 44:307-315.

17. Meyer BN, Ferrigni NR, Putnam JE, Jacobsen LB, Nichols DE, McLaughlin JL: Brine Shrimp: A convenient general bioassay for active plant constituents. Planta Med 1982, 45:31-34.

18. Ratnasooriya WD, Fernando TSP, Madubashini PP: In vitro thrombolytic activity of Sri Lankan black tea, Camellia sinensis (L.) O. Kuntze. J Natn Sci Foundation Sri Lanka 2008, 36(2):179-181.

19. Prasad S, Kashyap RS, Deopujari JY, Purohit HJ, Taori GM, Daginawala HF: Effect of Fagonia Arabica (Dhamasa) on in vitro thrombolysis. BMC Complement Altern Med 2007, 7:36.

20. Bauer AW, Kirby WM, Sherris JC, Turck M: Antibiotic susceptibility testing by a standardized single disk method. Am J Clin Pathol 1966, 45:493-496.

21. Saha A, Rahman MS: Antimicrobial Activity of Crude Extract from Calycopteris floribunsa. Bang J Microbiol 2008, 25:137-139.

22. Grover RK, Moore JD: Toximetric studies of fungicides against brown rot organism- Sclerotinia fructicola and S. laxa. Phytopathology 1962 52:876-880

23. Hossain MN, Fakruddin M, Islam MN: Effect of chemical additives on the shelf life of tomato juice. Am J of Food Tech 2011, 6(10):914-923.

24. Kasote DM, Hedge MV, Deshmikh KK: Antioxidant activity of phenolic components from n-Butanol fraction (PC-BF) of defatted flax seed meal. Am J Food Tech 2011, 6(7):604-612.

25. Vinson JA, Dabbagh YA, Serry MM, Jang J: Plant Flavonoids, Especially Tea Flavonols, Are Powerful Antioxidants Using an in vitro Oxidation Model for Heart Disease. J Agri Food Chem 1995, 43:2800-2802.

26. Elzaawely AA, Xuan TD, Tawata S: Antioxidant and antibacterial activities of Rumex japonicas HOUTT. Aerial Parts Biol Pharm Bull 2005, 28:2225-2230.

27. Wallace RJ: Antimicrobial properties of plant secondary metabolites. Proc Nutr Soc 2004, 63:621-29.

28. Lucy H, DaSilva EJ: Medicinal plants: A re-emerging health aid. Elect J Biotech 1999, 2:56-70. 
29. Koduru S, Grierson DS, Afolayan AJ: Antimicrobial activity of Solanum aculeastrum. Pharm Biol 2006, 44:283-86.

30. Okeke MI, Iroegbu CU, Eze EN, Okoli AS, Esimone CO: Evaluation of extracts of the root of Landolphia owerrience for antibacterial activity. J Ethnopharmacol 2001, 78:119-27.

31. Prakash O, Kumar R, Mishra A, Gupta R: Artocarpus heterophyllus (Jackfruit): an overview. Pharmacogn Rev 2009, 3:353-358.

32. McLaughlin JL: in Assays for Bioactivity. In Methods in Plant Biochem. 6th edition. Edited by Hostettmann K. San Diego, USA: Academic Press; 1991:1-32.

33. Fakruddin M, Alam KMA, Mazumdar RM, Islam S, Nipa MN, Iqbal A, Bhuiyan HR: Anti-bacterial Activity of the Extract of Terminalia arjuna Against Multi Antibiotic Resistant Vibrio cholerae. J Sci Res 2011, 3(1):129-137.

34. Sunita B, Mahendra R: Antifungal Activity of Essential Oils from Indian Medicinal Plants against Human Pathogenic Aspergillus fumigatus and $A$. niger. World J Med Sci 2008, 3(2):81-88.

doi:10.1186/1472-6882-12-232

Cite this article as: Fakruddin et al: Antibacterial, antifungal and antioxidant activities of the ethanol extract of the stem bark of Clausena heptaphylla. BMC Complementary and Alternative Medicine 2012 :.

\section{Submit your next manuscript to BioMed Central and take full advantage of:}

- Convenient online submission

- Thorough peer review

- No space constraints or color figure charges

- Immediate publication on acceptance

- Inclusion in PubMed, CAS, Scopus and Google Scholar

- Research which is freely available for redistribution 